Simón-Vallejo, M. D., Cortés-Sánchez, M., Finlayson, G., Giles-Pacheco, F., RodríguezVidal, J., Calle Román, L., Guillamet, E. and Finlayson, C. (2018): “Hands in the dark: Palaeolithic rock art in Gorham's Cave (Gibraltar)", Spal 27.2: 15-28. DOI: http://dx.doi.org/10.12795/spal.2018i27.14

\title{
HANDS IN THE DARK: PALAEOLITHIC ROCK ART IN GORHAM'S CAVE (GIBRALTAR)
}

\section{MANOS EN LA OSCURIDAD: ARTE PALEOLÍTICO EN GORHAM'S CAVE (GIBRALTAR)}

\author{
MARÍA D. SIMÓN-VALLEJO \\ Departamento de Prehistoria y Arqueología. University of Sevilla (Spain) \\ Correo-e: msimon@us.es Author ID: 24081325700, ORCID https://orcid.org/0000-0002-6885-1464 \\ MIGUEL CORTÉS-SÁNCHEZ \\ Departamento de Prehistoria y Arqueología. University of Sevilla (Spain) \\ Correo-e: mcortes@us.es Author ID: 24079481300, ORCID: http://orcid.org/0000-0001-9093-3338 \\ GERALDINE FINLAYSON \\ Gibraltar Museum, Gibraltar. 18-20 Bomb House Lane. PO Box 939, Gibraltar \\ Correo-e: geraldine.finlayson@gibmuseum.gi ORCID: https://orcid.org/0000-0002-1751-5655 \\ FRANCISCO GILES-PACHECO \\ Gibraltar Museum, Gibraltar. 18-20 Bomb House Lane. PO Box 939, Gibraltar \\ Correo-e: pacogiles@hotmail.es \\ JOAQUÍN RODRÍGUEZ-VIDAL \\ Departamento de Geodinámica y Paleontología, Facultad de Ciencias Experimentales, Campus del Carmen, University of Huelva, Huelva, Spain \\ Correo-e: jrvidal@dgeo.uhu.es ORCID: https://orcid.org/0000-0002-9475-3307 \\ LYDIA CALLE ROMÁN \\ HUM-949. Tellus. Prehistoria y Arqueología en el sur de Iberia. University of Sevilla (Spain) \\ Correo-e: arqueolydi83@hotmail.com ORCID: https://orcid.org/0000-0002-9894-512X \\ EUDALD GUILLAMET \\ Restorer of Cultural Heritage, Andorra \\ Correo-e: eguillamet@yahoo.es \\ CLIVE FINLAYSON \\ Gibraltar Museum, Gibraltar. 18-20 Bomb House Lane. PO Box 939, Gibraltar \\ Correo-e: clive.finlayson@gibmuseum.gi ORCID: https://orcid.org/0000-0003-4795-9430
}

\begin{abstract}
The work in the inner area of Gorham's Cave, Gibraltar, has added to the Palaeolithic art located in the cave. Although work continues on the surveying and the study of the evidence found up to now, we present here a preview consisting of a representation of a red deer, and also a hand stencil, alongside numerous marks which have been found scattered throughout the inner cave. In this paper we present new data on the Upper Palaeolithic rock art in Gorham's Cave (Gibraltar) including direct dating of a hand stencil. Situating this dating in the archaeological context of the stencil, we conclude that it is associated with the Solutrean
\end{abstract}

Resumen: Los trabajos en la zona más interior de la cueva de Gorham (Gibraltar) han ampliado la zona con arte rupestre paleolítico en la cavidad. Aunque los trabajos continúan, presentamos en este trabajo un avance de los nuevos hallazgos, un ciervo y una mano en negativo, así como numerosos trazos. Así mismo, damos a conocer la datación directa mediante ${ }^{14} \mathrm{C}$-AMS de una mano en negativo y situamos el resultado obtenido en el contexto del registro arqueológico de Gorham, que nos lleva a proponer una ejecución durante el Solutrense evolucionado. El resultado es particularmente significativo a la luz del encuadre convencional a este tipo de 
technocomplexe. This is particularly significant in the light of recent reviews which put European hand stencils in the context of the Early or Initial Upper Palaeolithic. In this context, the Gorham data opens the discussion on the systematic chronological correlation of all hands in negatives of European Palaeolithic rock art.

Keywords: Upper Palaeolithic; Rock art; Hands stencils; Chronology; Solutrean; Gibraltar

\section{INTRODUCTION}

Hand stencils on cave walls were first discovered at the turn of the $20^{\text {th }}$ Century. Since then, a number of such stencils have been discovered in Europe and the consensus has been to attribute these to the Upper Palaeolithic, specifically the Gravettian-Aurignacian. Recently, some authors have re-examined the evidence and have concluded that in all or almost all known cases, these hand stencils are older than the Gravettian (García-Díez and Garrido 2013, García-Díez et al. 2015, Pettitt et al. 2015, Hoffmann et al. 2017) and, in some exceptional cases, some authors manage to frame it in the Middle Palaeolithic (Hoffman et al. 2018a).

Gibraltar has a large number of Pleistocene archaeological sites (e.g. see Finlayson et al. 2000), the best-known being Gorham's Cave (fig. 1), where a long sequence of Middle Palaeolithic levels have been identified, and which also has other more recent levels belonging to the Solutrean and Magdalenian as well as Holocene levels (Finlayson et al. 2006). In this sense, these authors published nine radiocarbon dates from within the Upper Palaeolithic levels which are likely to correspond, on the basis of style, to a series of rock paintings and engravings that have been recorded in the outer area of the cave (Balbín et al. 2000, fig. 1.4). In order to systematically study these elements of rock art, the Gibraltar Rock Art Project (GI.R.A. Project) was launched with the aim of identifying and studying the artistic archaeology of Gibraltar in the context of the hunter-gatherer territory models of occupation in the Upper Palaeolithic in the South of Iberia (Simón et al. 2005, 2008). In this case, Gorham's Cave is the main feature within the Rock of Gibraltar which is a major landmark in the Strait of Gibraltar (Simón et al. 2008).

Here we report on the discovery of a hand stencil in Gibraltar (fig. 1), at the south westernmost extreme of Europe ( $36^{\circ} 7$ ' $\left.14.32^{\prime \prime} \mathrm{N}, 5^{\circ} 20^{\prime} 31.2^{\prime} \mathrm{W}\right)$, situate it chronologically, and assess its importance in the context of current interpretations of the cultural attribution de motivos, atribuidos normalmente a momentos antiguos del Paleolítico Superior. En este contexto, el dato de Gorham abre la discusión sobre esta correlación sistemática de todas las manos en negativos del arte paleolítico europeo.

Palabras claves: Paleolítico Superior; Arte rupestre; Manos en negativo; Cronología; Solutrense; Gibraltar.

of hand stencils in the context of European Palaeolithic rock art.

\section{GORHAM'S CAVE}

The existence of Palaeolithic art in Gorham's Cave was detected near to the excavated sections (Balbín et al. 2000) where both zoomorphic and idiomorphic paintings and engravings have been documented (fig. 1.4 and fig. 2). In 2005, we continued the exploration of the various areas not previously studied: these included the outer zones of the cave and Inner Gorham's Cave, an interior section within which only surveying work had been carried out.

'Inner Gorham's Cave' (fig. 1.4) is so named after an inscription left on the wall by Captain A. Gorham, of the $2^{\text {nd }}$ Battalion Royal Munster Fusiliers, which reads "Discovered and opened by Capt. Gorham. R.M.F.s + S Sgt Mathews. Jan. 1907'. This indicates that the entrance to this part of the cavity was practically hidden by Holocene sediments containing Neolithic and Phoenician archaeological remains which once blocked the entrance, and which still remain on the surface of this section of the gallery.

Current access (fig. 1.4) to Inner Gorham's Cave is through a narrow passage - located about $9 \mathrm{~m}$ from the end of the main gallery - only $45-50 \mathrm{~cm}$ at its narrowest point, formed between the rock (above) and the top of the sediments on the base. This passage is about $9 \mathrm{~m}$ long, and leads into a gallery about $25 \mathrm{~m}$ in length which has a similar orientation to the main axis of the main cave outside. Inner Gorham's Cave is divided transversely by hanging blocks which have been formed by erosion of sub-vertical fractures by the sea and by chemical corrosion.

Inner Gorham's Cave also has speleothems at floor level and low heights, which make it impossible for a person to stand up anywhere in the area, except in a very few points where one can just about wedge in between walls. There are also some smaller passages that gradually narrow until they are completely impenetrable. 


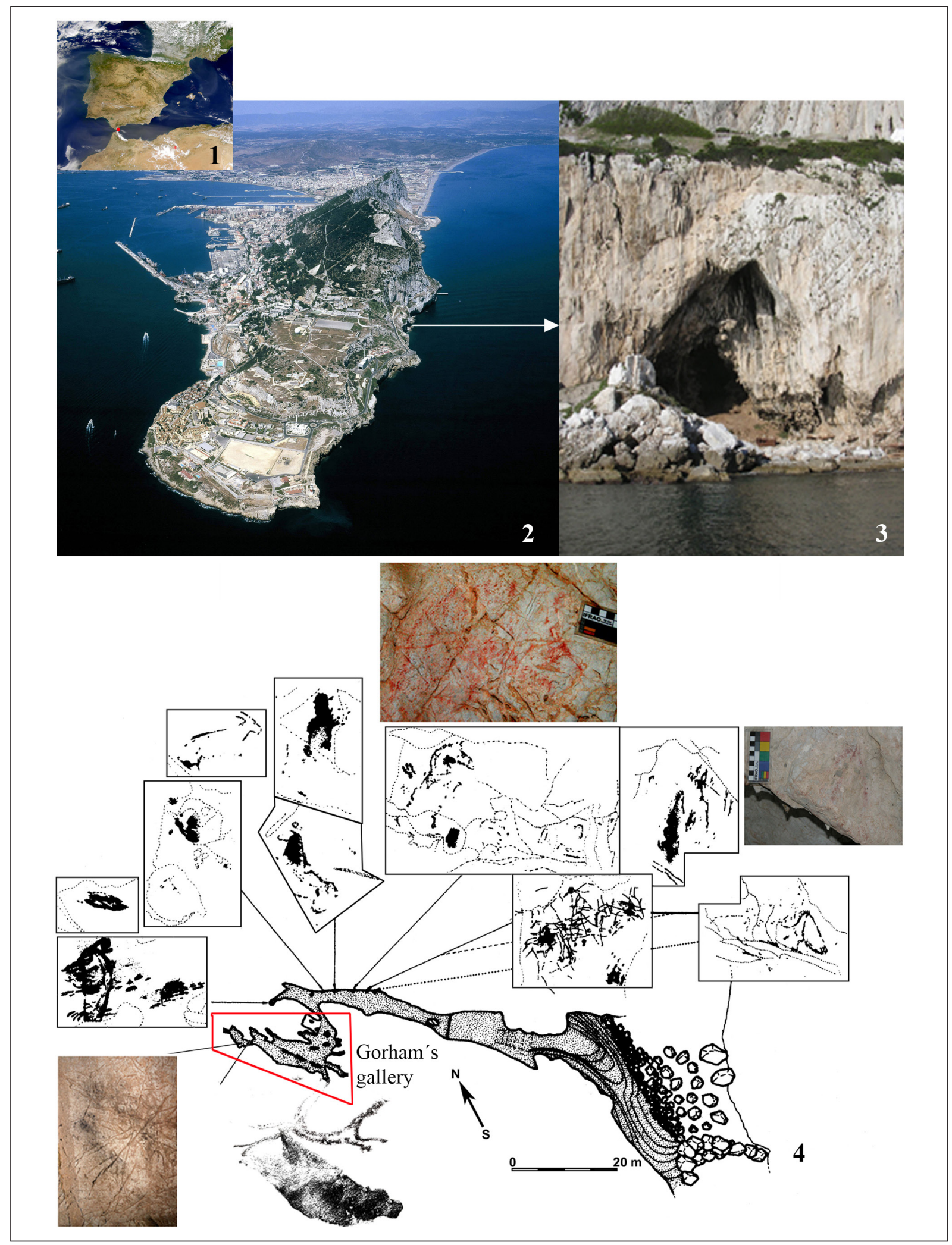

Figure 1. Gorham's cave Palaeolithic rock art. Showing the location of the site, and the positions of the rock art within Gorham's Cave.

ISSN: 1133-4525 ISSN-e: 2255-3924

SPAL 27.2 (2018): 15-28 http://dx.doi.org/10.12795/spal.2018i27.14 


\section{METHODS}

The 14C-AMS sample, extracted by one of the authors (EG), was obtained by following not only strict sampling methods, but also prime conservation methods so that the loss of pigment from the figure did not prevent the preservation of the motif or mislead in its interpretation. The sample was collected under the direct supervision and permission of the Director of the Gibraltar Museum.

To obtain the necessary quantity, 12 microsamples were extracted from different parts of the halo of Hand-1 (fig. 3.6), totalling $96 \mathrm{mg}$, which after treatment in the Beta Analytic Laboratory, was reduced to $20.8 \mathrm{mg}$ of fine-grained dark brown-speckled residue which was the analysed sample $(100 \% \mathrm{C})$. The analysis was carried out in a ${ }^{14} \mathrm{C}$ accelerator-mass-spectrometer (AMS) located at one of the six collaborating research facilities of the laboratory. This sample did not have a measured radiocarbon age and no ${ }^{13} \mathrm{C} /{ }^{12} \mathrm{C}$ ratio as reported. This was because the sample was too small to do a separate ${ }^{13} \mathrm{C} /{ }^{12} \mathrm{C}$ ratio and AMS analysis. The only ${ }^{13} \mathrm{C} /{ }^{12} \mathrm{C}$ ratio available to calculate a Conventional $\mathrm{Ra}-$ diocarbon Age was that determined on a small aliquot of graphite. Although the ratio corrects to the appropriate Conventional Radiocarbon Age, it was not reported since it included laboratory chemical and detector induced fractionation. A ratio including both natural and laboratory effects was measured during the ${ }^{14} \mathrm{C}$ detection to derive a Conventional Radiocarbon Age which was suitable for applicable calendar calibration.

One of the short comings of the AMS method of dating for Palaeolithic rock art is the possibility of incorporation of carbonates in the samples (Pons-Branchu et al. 2014). In the case of the samples from Gorham's Cave, the carbon sampled was from crevices in the rock with no type of carbonate crust over them, and these were extracted using sterile tools and with the use of binocular magnifying equipment in order to avoid incorporating elements from the wall of the cave, thereby avoiding the problem of contamination.

\section{RESULTS}

\section{a) Red Deer Stag}

The first representation, a zoomorphic figure is found on a ledge of the roof of the cave, located about 40 $\mathrm{cm}$ above the current floor. The painting represents the front third of a red deer (fig. 2.2). This figure is $40 \mathrm{~cm}$ long by $27 \mathrm{~cm}$ wide and was executed by using a brush to apply a liquid preparation of nearly black pigment. The animal has been drawn with perspective and in profile showing the left side of the body, while the antlers are also in profile, except for the brow tines which start from the crown in parallel lines, and diverge away from the crown. The lower jaw is painted in black pigment, a vertical line forms a closed square to represent the nose, and another line traces the forehead to reach the pedicle or base of the horns, after which it continues outlining the arch of the back with a very fine thin line. The antler has been expressed in a clear and detailed manner showing the different parts of the horns: brow tine, bay antler and royal antler, the latter being represented with two lines while three lines are used to represent the crown tines. Finally, diluted black pigment was rubbed into the area of the neck, the top of the chest and part of the head.

The end result is a well-proportioned figure, where the pigments have been used to enhance the existing textures of the rock to obtain an effect of some volume, especially in the neck of the animal which, with adequate lighting, evokes a shallow bas-relief.

From the point of view of conservation, the panel where the red deer is located is subject to the same processes of carbonate deposits observed in other parts of the cave, and which have concealed some areas of pigment, such as in the tip of the antlers and part of the mandible (fig. 2.2). However, the predominant erosion process is the washing and dissolution of carbonates which has caused the disappearance of pigment, leaving only the part absorbed by the rock, so that both the colours and lines appear faded.

A final detail to note is a patch of carbide residue partially conceals the crown of the red deer (fig. 2.2), an indication of a caving expedition from the twentieth century.

\section{b) Hand Stencil}

The second representation of parietal art is a stencil (fig. 3), formed by projecting or spraying black pigment over a hand and right forearm (Hand-1). The stencil is located directly on the wall of the cave in an area which has no speleothems near the back of Inner Gorham's Cave at the bifurcation between the main gallery and the blind gallery to the side (figs. 1.4 and 3.1 ), just at the point where the first gallery begins to narrow until it becomes too impractical for progression along it 


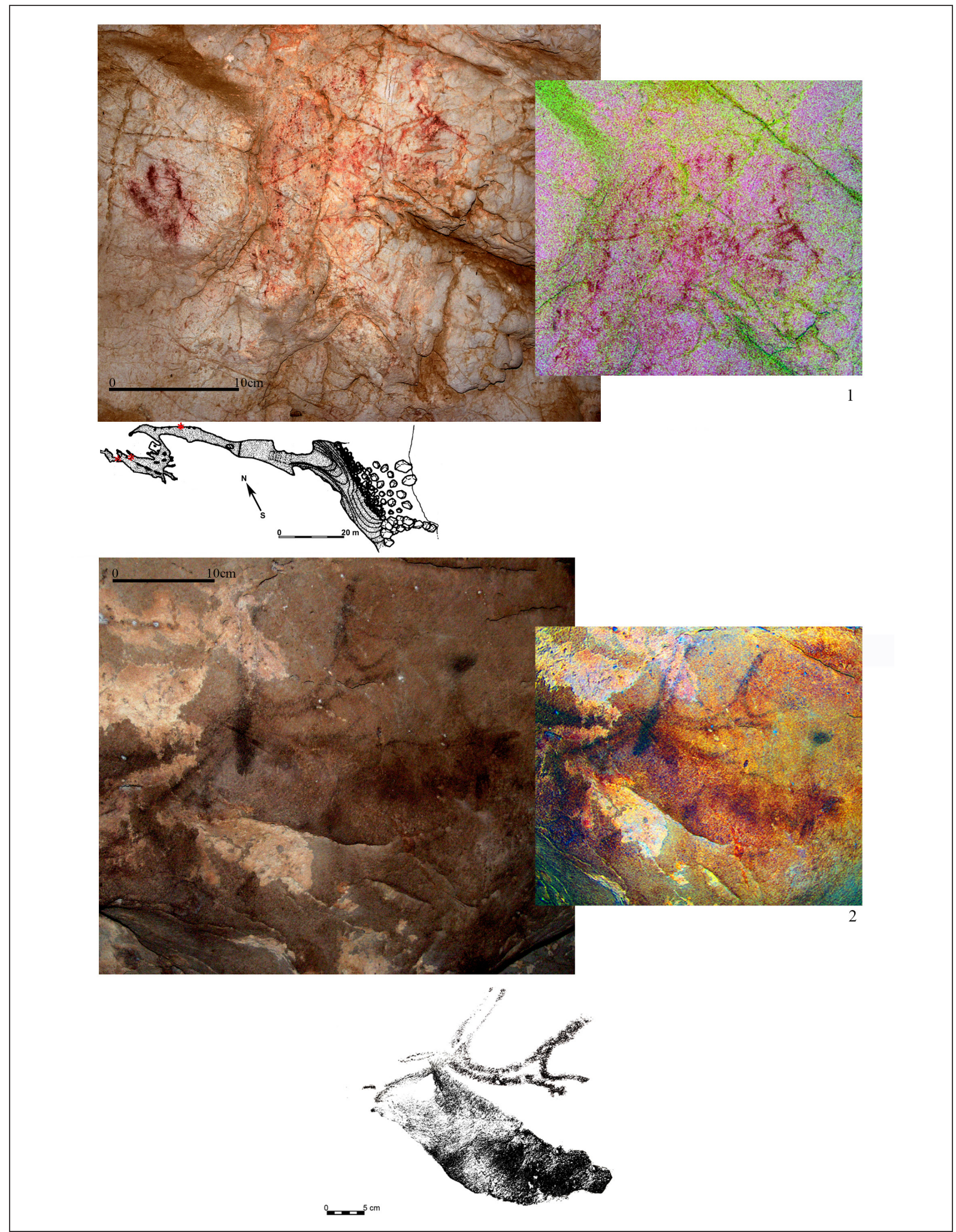

Figure 2. Palaeolithic rock art from Gorham's cave. 1) Horse is located in the main gallery area, 2) Red Deer is within Inner Gorham's Cave.

ISSN: $1133-4525$ ISSN-e: 2255-3924 


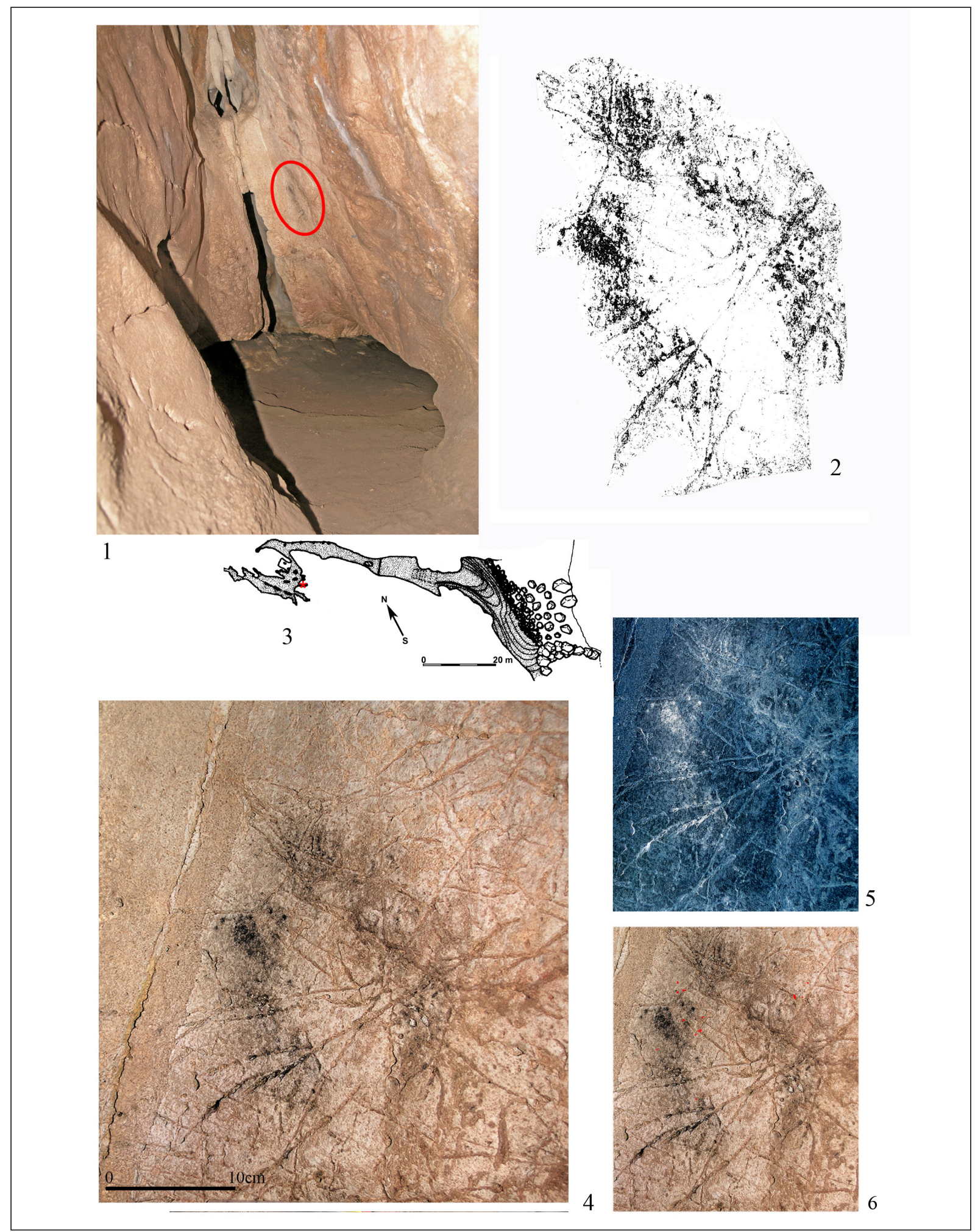

Figure 3. Location and detail of hand-1. 1) Panel where the Hand-1 is located, 2) Drawing of Hand-1, 3) Plan of Gorham's Cave showing the position of the panel, 4-5) Details of Hand-1,6) The 12 samples extracted from different areas within the halo are shown in red. 
After analysing the topographic characteristics of the site (fig. 3.1), it can be argued that in this area there is only room for one person of slight build. Therefore, it is likely that this is the work of a single individual; projecting the pigment while supporting themselves by placing their right hand on the wall. The small size of the hollow in the rock forced the artist's hand to take a somewhat unnatural position, as shown in the figure, where the foreshortening of the wrist and fingers can be observed. Furthermore, flexion of these, especially the index and middle fingers, indicates that the back of the hand was placed flat against the rock to compensate for the space limitations.

Finally, from the scatter pattern in the 'halo' and the density distribution of pigment combined with the geometry of the interior, it can be concluded that the hand was positioned slightly above the origin of projection of the pigment which was also slightly to the left of the axis of the hand.

Due to various factors (unnatural position of the hand, blurring of anatomical features and poor conservation of some areas) it is impossible to obtain all the anthropometric measurements necessary to make a calculation of the individual's body size (i.e. Sahly 1966, Ripoll et al. 1999). However, the significant dimensions (width of the wrist, overall size of the palm and fingers) would suggest a hand of small dimensions and an individual of a height substantially below $170 \mathrm{~cm}$, possibly a woman or, most likely, a child or youth, since the most reliable measurement which seems to be the dimension of the width of the wrist, did not reach $4.8 \mathrm{~cm}$.

The cave wall has a strong physical-chemical alteration which has affected the rock art and caused substantial fading of the pigment. However, the combination of reduced space, the closeness between the artist and the wall, as well as the presence of cracks in the rock, have all played an important role in preserving some of the pigment embedded deep within them. This fact supports the conclusion that the imprint of the hand was not performed by dabbing, but by blowing/ spraying the pigment.

An attempt was made to date the hand. Thus, after testing the possibility that there was enough pigment in the 'halo' of Hand-1 and that it had an organic, it was decided to attempt its dating by ${ }^{14} \mathrm{C}$-AMS. The obtained date, 20,210-20,750 cal BP (table 1, fig. 4), coincided with the archaeological context in the cave. The main Upper Palaeolithic human presence in the cave coincides with the Solutrean which is well dated. Later, Upper Palaeolithic occupation refers to the Magdalenian. There is no Aurignacian or Gravettian recorded in the cave, or indeed any other cave in Gibraltar. Put together, the evidence strongly favours a Solutrean attribution to the hand stencil. In summary, the data point to a possible Solutrean attribution for the hand stencil of Gorham`s.

Table $1 .{ }^{14} \mathrm{C}$-AMS dates from archaeological excavations in Gorham's Cave and Hand-1. Except for Hand-1*, Level III dating Gorham's Cave (Finlayson et al. 2006). Radiocarbon has been calibrated using Oxcal 4.3 software (https://c14.arch.ox.ac.uk/oxcal.html) along with Intcal13 and marine13 curves (Reimer et al., 2013). Level III is separable into an upper level (IIIA) and a lower (IIIB) on archaeological (technology) grounds supported by dates. Level IIIA corresponds to the Magdalenian and IIIB to the Solutrean (Finlayson et al. 2006).

\begin{tabular}{|c|c|c|c|c|c|}
\hline $\begin{array}{l}\text { Gorham's } \\
\text { Cave }\end{array}$ & $\begin{array}{l}\text { Laboratory } \\
\text { code }\end{array}$ & $\begin{array}{c}\text { AMS age } \\
\text { conventional yr BP }\end{array}$ & $\begin{array}{c}\text { Calibrated AMS } \\
\text { date }(2 \sigma) \text { yr BP }\end{array}$ & $\begin{array}{l}\text { Material } \\
\text { culture }\end{array}$ & $\begin{array}{l}\text { Motif } \\
\text { art }\end{array}$ \\
\hline \multirow{6}{*}{ Level IIIa } & Beta-181896 & $13,870 \pm 80$ & $16,480-17,080$ & \multirow{6}{*}{ Magdalenian } & \multirow{6}{*}{ - } \\
\hline & Beta- 185343 & $10,880 \pm 80$ & $12,680-12,970$ & & \\
\hline & Beta-181895 & $12,460 \pm 100$ & $14,180-15,070$ & & \\
\hline & Beta- 184047 & $12,640 \pm 100$ & $14,430-15,320$ & & \\
\hline & Beta-196780 & $13,820 \pm 100$ & $16,360-17,050$ & & \\
\hline & Beta-196777 & $12,540 \pm 100$ & $14,260-15,160$ & & \\
\hline Rock art & Beta- 238027 & $16,990 \pm 90$ & $20,210-20,750$ & Rock art & Hand-1* \\
\hline \multirow{2}{*}{ Level IIIb } & Beta-181893 & $16,420 \pm 120$ & $19,520-21,110$ & \multirow{2}{*}{ Solutrean } & \multirow{2}{*}{ - } \\
\hline & Beta-184042 & $18,440 \pm 160$ & $21,880-22,610$ & & \\
\hline
\end{tabular}




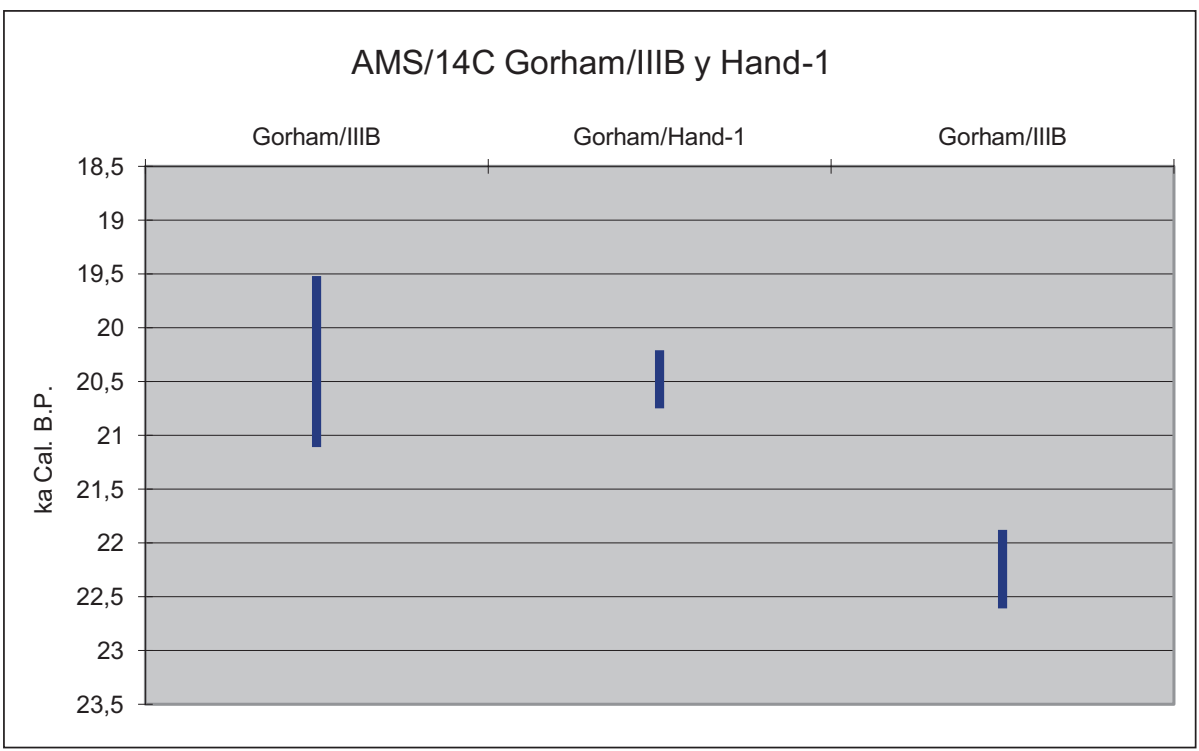

Figure $4 .{ }^{14} \mathrm{C}$-AMS dating cal ka BP (IntCal13,

Reimer et al. 2013) from Gorham's Cave, Level III and Hand-1.
Furthermore, if we compare the two dates for Level IIIB (table 1, fig. 4), it can be observed that there is an overlap between the calibrated ranges between the hand and one of the Solutrean dates, with the third being close to these dates. They all correspond to the lower parts of Level IIIB, from which material culture characteristics of an evolved Solutrean have been recovered (Finlayson et al. 2006). This further strengthens our result that the hand stencil corresponds to the Solutrean.

\section{DISCUSSION AND CONCLUSIONS}

From an iconographic point of view, the negative hand stencils are not numerous among sites with European Palaeolithic art, with only 33 sites (fig. 5) so far out of just over 300 documented with rock art (i.e. Pettitt et al. 2015 with references). Due to the exposure of the pigments, palaeolithic cave art dating presents a very particular problem. Thus, several authors have emphasized postdepositional processes that can alter the results in the actual sampling processes (i.e. Fortea 2002, 2007, Jurado et al. 2009, Sánchez del Moral et al. 2014).

The sample did not receive the conventional pretreatment currently received by the carbon samples (nynhydrin and especially ultrafiltration) nor could the ${ }^{13} \mathrm{C} /{ }^{12} \mathrm{C}$ ratio be measured.

Although at some site (i.e. Fuente del Salín) some late direct dating of a handprint has been obtained, the authors themselves have discarded it because there is a high probability that the sample was contaminated (García-Díez and Garrido 2013: 520-521, García-Díez et al. 2015: 9), so that the only direct dating of hands in negative comes from Cosquer, whose result points to a Gravettian age (Clottes and Courtin 1994), while the rest are of an indirect nature (Pettitt et al. 2015, Hoffmann et al. 2017). So that, in terms of chronological assignment, the direct and indirect dating of negative hand stencils in European Pleistocene art (Table 2) have recently come to be associated with Early or Initial Upper Palaeolithic (i.e. García-Díez and Garrido 2013, GarcíaDiez et al. 2015, Pettitt et al. 2015) and, exceptionally, to the Middle Palaeolithic (Hoffmann et al. 2018a), although this attribution is under discussion (see Pearce and Bonneau 2018, Hoffmann et al. 2018b, Aubert et al. 2018). In this paper we report on the discovery of a hand stencil at the south westernmost extreme of Europe, on the very limit of the geographical range of Upper Palaeolithic Europeans. Our results suggest a Solutrean context for the execution of the hand stencil.

This result should not be used simply to reverse the allocation given to other negative hands, without further direct dating in European Palaeolithic art. However, it also presents us with a complex reality that cannot be ignored. In this sense the ${ }^{14} \mathrm{C}$-AMS Gorham's Cave date suggests that these representations reach chronologies postgravettian.

Additionally, it should be considered that some of the proxy data used for dating the hands in negative per se does not confirm this allocation. For example, in Castillo (table 3) the two dates for the bison which have 
Figure 5. Western Europe sites with negative hands stensils: 1. Margot,

2. Arcy-sur-Cure, 3. Chauvet, 4. Cosquer, 5. Pech-Merle, 6. Paglicci, 7. Les Merveilles,

8. Roucadour, 9. Moulinde-Laguenay, 10. Les Combarelles I, 11. Font de Gaume, 12. Poisson, 13. Bernifal, 14. Bison, 15. Abri Labattut, 16. Roc-de-Vézac, 17. Cougnac, 18. Le Fieux, 19. Vilhonneur, 20. Les Trois-Frères, 21. Tibiran, 22. Gargas, 23. Erbérua, 24. Altamira, 25. El Castillo, 26. Cudón,

27. La Garma, 28. La

Fuente del Salín, 29. Tito Bustillo, 30. La Fuente del

Trucho, 31. Maltravieso, 32. Ardales, 33. Gorham's Cave.

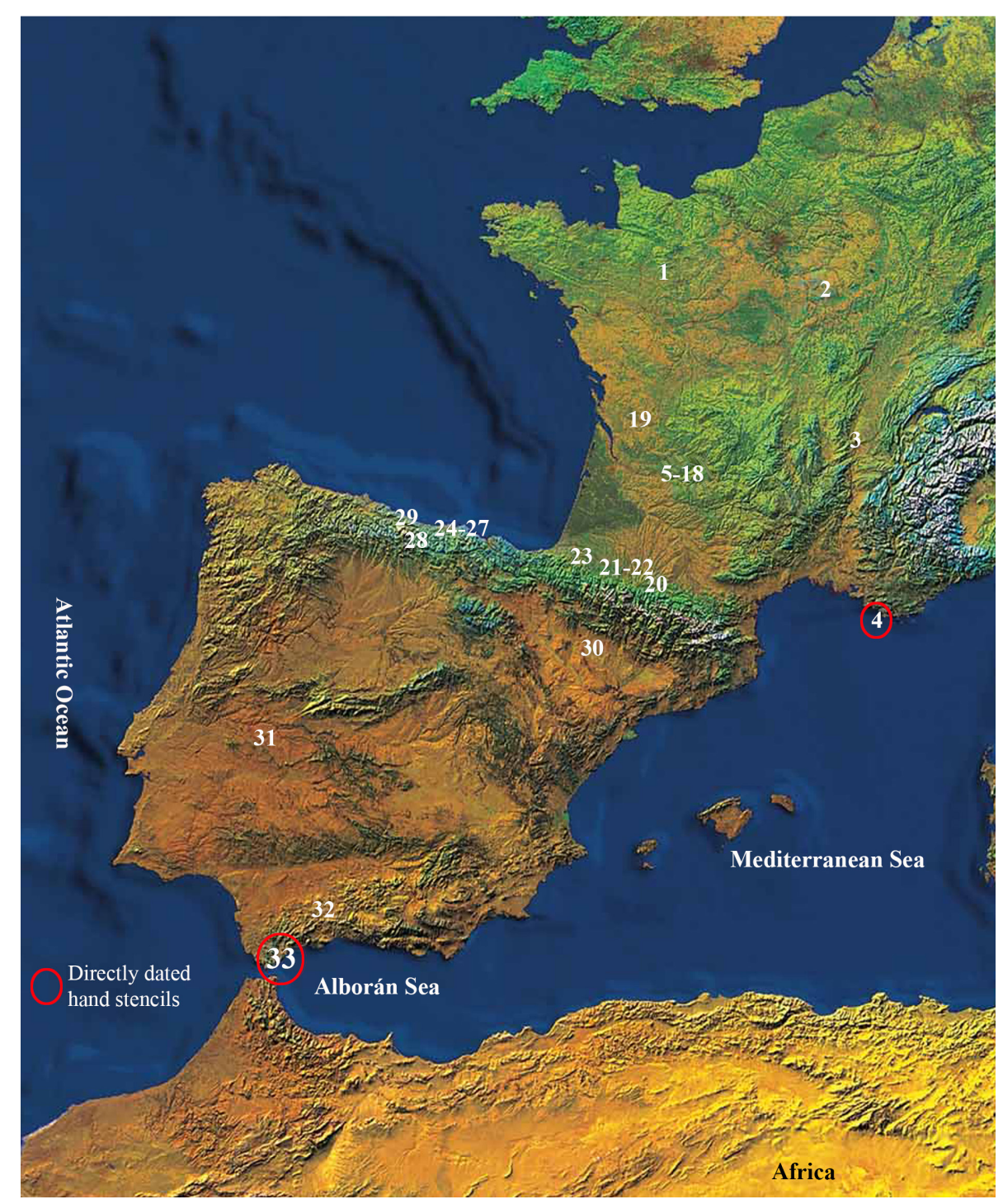

superimposed hands only indicate an age ante quem for the creation of these (Pike et al. 2012). In Pech-Merle, the negative hands within the panel of the horses are given the same dates as that obtained by the direct dating of one of the horses, but it must be remembered that in this case, the hand stencils in this site appear around the horses not underneath them. Furthermore, the date obtained on a reindeer metacarpal with evidence of de-fleshing found at the foot of this panel and dated at 18,400+350 BP (Lorblanchet 1995: 270), indicates the "anthropic presence" in the environment of the panel during a cold phase (Last Glacial Maximum on the basis of the date and the species identified) which would be after the painting of the horses.

In the case of Labattut, it must be noted that it was excavated in 1912 and re-evaluated at the end of the twentieth century, and that it consisted of a very thin Solutrean level (Baffier and Girard 1992).

It follows therefore that whilst stylistic aspects in the study of Palaeolithic art are important, they should always be considered, as noted by J. Fortea (2005), within an archaeological context.

In the case of the Hand-1, the radiocarbon date should alert us to the danger of creating the circular argument of assigning all motifs of this kind, and by extension the negative impressions of hands and fingers or even symbols that evoke the European Palaeolithic Gravettian art when, as described by many authors (for example, Lorblanchet 1995), the evidence provided in the panels of caves with Palaeolithic art responds to very complex processes, and in many cases, 
Table 2. Data linked to hands stencils in European palaeolithic rock art. (*) Indirect dating from overlying crust. Sites located in Figure 5.

\begin{tabular}{|c|c|c|c|c|c|c|}
\hline Site & \multicolumn{2}{|c|}{$\begin{array}{l}\text { AMS date } \\
\text { yr BP }\end{array}$} & $\begin{array}{l}\text { Cal. age } \\
\text { yr BP }\end{array}$ & $\begin{array}{l}\text { Laboratory } \\
\text { code }\end{array}$ & Origin & Reference \\
\hline \multicolumn{7}{|c|}{ Direct dating } \\
\hline Gorham's Cave & \multicolumn{2}{|c|}{$16,990 \pm 90$} & $20,210-20,750$ & Beta-238027 & Hand negative 1 & This paper \\
\hline \multirow{6}{*}{ Cosquer } & \multicolumn{2}{|c|}{$27,110 \pm 390$} & $30,520-31,730$ & GiF A-92409 & \multirow{3}{*}{$\begin{array}{l}\text { Hand negative } 7 \\
\text { (Panel I) }\end{array}$} & \multirow{3}{*}{ Clottes et al. 1994} \\
\hline & \multicolumn{2}{|c|}{$27,110 \pm 350$} & & & & \\
\hline & \multicolumn{2}{|c|}{$26,180 \pm 330 *$} & & & & \\
\hline & \multicolumn{2}{|c|}{$24,840 \pm 340$} & $28,110-29,650$ & \multirow{2}{*}{ GiF A-95358 } & \multirow{2}{*}{$\begin{array}{l}\text { Hand negative } 12 \\
\text { (Panel III) }\end{array}$} & \multirow{3}{*}{ Clottes et al. 1996} \\
\hline & \multicolumn{2}{|c|}{$23,150 \pm 620^{*}$} & $26,090-29,650$ & & & \\
\hline & \multicolumn{2}{|c|}{$27,740 \pm 410$} & $31,000-32,710$ & GiF A-96073 & $\begin{array}{l}\text { Hand negative } 19 \\
\text { (Panel III) }\end{array}$ & \\
\hline \multicolumn{7}{|c|}{ Indirect dating by association, overlap or linkage } \\
\hline \multirow[t]{2}{*}{ Fuente del Salín } & \multirow{2}{*}{22,340} & +510 & \multirow{2}{*}{$25,740-27,530$} & \multirow{2}{*}{ GrN18574 } & \multirow{2}{*}{ Charcoal nearby hearth } & \multirow{2}{*}{$\begin{array}{l}\text { Moure and González } \\
1992\end{array}$} \\
\hline & & -480 & & & & \\
\hline $\begin{array}{c}\text { Fuente } \\
\text { del Trucho }\end{array}$ & \multicolumn{2}{|c|}{$\begin{array}{l}\geq 25,110(\mathrm{U} / \mathrm{Th}) \\
\geq 26,050(\mathrm{U} / \mathrm{Th}) \\
\geq 25,200(\mathrm{U} / \mathrm{Th}) \\
\geq 25,720(\mathrm{U} / \mathrm{Th}) \\
\geq 26,400(\mathrm{U} / \mathrm{Th}) \\
\geq 26,730(\mathrm{U} / \mathrm{Th}) \\
>26,240(\mathrm{U} / \mathrm{Th}) \\
\geq 27,370(\mathrm{U} / \mathrm{Th})\end{array}$} & $>25.110$ & $\begin{array}{l}\text { FT-1a } \\
\text { FT-1b } \\
\text { FT-2b } \\
\text { FT-2c } \\
\text { FT-8 } \\
\text { FT-9 } \\
\text { FT-10 } \\
\text { FT-11 }\end{array}$ & $\begin{array}{l}\text { Hand negative } 1 \mathrm{a} \\
\text { Hand negative } 1 \mathrm{~b} \\
\text { Hand negative } 2 \mathrm{a} \\
\text { Hand negative } 2 \mathrm{c} \\
\text { Hand negative } 8 \\
\text { Hand negative } 9 \\
\text { Hand negative } 10 \\
\text { Hand negative } 11\end{array}$ & Hoffmann et al. 2017 \\
\hline Gargas & \multicolumn{2}{|c|}{$26,860 \pm 460$} & $29,900-31,580$ & GiFA-92369 & Bone in fissure & Clottes et al. 1992 \\
\hline Pech-Merle & \multicolumn{2}{|c|}{$24,640 \pm 390$} & $27,870-29,500$ & Gif A-95357 & Horse & Lorblanchet et al. 1989 \\
\hline Abri Labattut & \multicolumn{6}{|c|}{ Block fallen from the ceiling in Gravettien layer } \\
\hline Castillo & \multicolumn{2}{|c|}{$\geq 13,060 \pm 200$} & Hand $>15,100$ & Gif A-91004 & $\begin{array}{l}\text { Bison } 18 \mathrm{a} \text { on hand ne- } \\
\text { gative red }\end{array}$ & \multirow{2}{*}{ Valladas et al. 1992} \\
\hline Castillo & \multicolumn{2}{|c|}{$\geq 12,910 \pm 180$} & Hand $>14,800$ & Gif A-91172 & $\begin{array}{l}\text { Bison } 18 \mathrm{~b} \text { on } 4 \text { hand ne- } \\
\text { gative red }\end{array}$ & \\
\hline Castillo & \multicolumn{2}{|c|}{$\begin{array}{l}\geq 24,340 \pm 120 \\
(\mathrm{U} / \mathrm{Th})\end{array}$} & - & $\begin{array}{c}\mathrm{O}-58 \\
(\text { Corrected age })\end{array}$ & $\begin{array}{l}\text { Overlay red stippled ne- } \\
\text { gative hand stencil * }\end{array}$ & \multirow{3}{*}{ Pike et al. 2012} \\
\hline Castillo & \multicolumn{2}{|c|}{$\begin{array}{c}\geq 37,630 \pm 340 \\
(\mathrm{U} / \mathrm{Th})\end{array}$} & - & $\begin{array}{c}\mathrm{O}-82 \\
(\text { Corrected age })\end{array}$ & $\begin{array}{l}\text { Sample overlays red ne- } \\
\text { gative hand stencil* }\end{array}$ & \\
\hline Castillo & \multicolumn{2}{|c|}{$\begin{array}{c}\geq 41.4 \pm 0.57 \mathrm{BP} \\
(\mathrm{U} / \mathrm{Th})\end{array}$} & $\begin{array}{c}\text { Carbonate crusts } \\
\text { Hand stencil } \\
>41.4 \mathrm{ka}\end{array}$ & $\begin{array}{l}\text { U-series: O-83 } \\
\text { (Corrected age) }\end{array}$ & $\begin{array}{l}\text { Sample overlays red ne- } \\
\text { gative hand stencil* }\end{array}$ & \\
\hline Maltravieso & \multicolumn{2}{|c|}{$\begin{array}{c}\geq 66.7 \mathrm{ka} \\
(\mathrm{U} / \mathrm{Th})\end{array}$} & $\begin{array}{c}\text { Carbonate crusts } \\
\text { Hand stencil }\end{array}$ & $\begin{array}{c}\text { U-series: } \\
\text { (Corrected age) }\end{array}$ & $\begin{array}{l}\text { Sample overlays red ne- } \\
\text { gative hand stencil* }\end{array}$ & Hoffmann et al. 2018a \\
\hline
\end{tabular}


Table 3. Elaborated from data collected by Clottes and Coutin 1994, Ripoll et al. 1999, Mussi 2002, Clottes 2003, González 2003, Lasheras 2003, Cantalejo et al. 2006, Pigeot et al. 2006, Foucher et al. 2007, Gambier et al. 2007, Pettitt and Pike 2007, Pike et al. 2012, Utrilla et al. 2014, Hoffmann et al. 2017.

Sites with $\geq 10$ hand stencils and groups

\begin{tabular}{|l|c|}
\hline \multicolumn{1}{|c|}{ Site } & $\mathrm{N}^{\mathrm{o}}$ \\
\hline Gargas & 194 \\
\hline Castillo & 85 \\
\hline Fuente del Trucho & $>50$ \\
\hline Maltravieso & 68 \\
\hline Cosquer & 65 \\
\hline La Garma & 39 \\
\hline Tibiran & 18 \\
\hline Pech-Merle & 16 \\
\hline Les Fieux & 14 \\
\hline La Fuente del Salín & 12 \\
\hline Roucadour & 10 \\
\hline
\end{tabular}

is heterogeneous from a chronological and spatial point of view and, one might add, behavioural and cultural.

In this sense, this brief review of the better known sites with these types of figures reveals the large geographic extent of these, which reach their western extreme with the new depiction in Gorham's Cave. In addition, a brief quantitative, qualitative and topographic analysis of the sites permits them to be grouped into two types (Table 2):

a) Firstly, those which have numerous representations of hands, where these are arranged in groups,
Sites with $<10$ hand stencils or more dispersed disposal

\begin{tabular}{|l|l|}
\hline \multicolumn{1}{|c|}{ Site } & $\mathrm{N}^{\mathrm{o}}$ \\
\hline Grande Grotte d'Arcy-sur-Cure & 8 \\
\hline Chauvet & 7 \\
\hline Les Merveilles & 6 \\
\hline Les Trois-Frères & 5 \\
\hline Font-de-Gaume & 5 \\
\hline Margot & 5 \\
\hline Bernifal & 4 \\
\hline Erbérua & 3 \\
\hline Paglicci & 3 \\
\hline Bison & 2 \\
\hline Moulin-de-Laguenay & 2 \\
\hline Roc de Vézac & 2 \\
\hline Altamira & 2 \\
\hline Tito Bustillo & 1 \\
\hline Les Combarelles I & 1 \\
\hline Cougnac & 1 \\
\hline Abri du Poisson & 1 \\
\hline Abri Labattut* & 1 \\
\hline Cudón & 1 \\
\hline Ardales & 1 \\
\hline Vilhonneur & 1 \\
\hline Gorham's Cave & \\
\hline
\end{tabular}

concentrated in restricted areas within the caves and occupying conspicuous places or main panels in the path of the cave (Gargas, Cosquer, Fuente del Trucho or Maltravieso).

b) Secondly, sites with representations of far fewer hands, usually limited to a few units scattered throughout the caverns.

Whether these groupings are random, or whether they represent specific spatiotemporal trends is an issue that will require further data and a more detailed analysis 
which is beyond the scope of this work, although the evidence of the Hand-1 cannot be ignored.

In conclusion the data from Gorham's Cave present a topo-iconographic motif that appears to coincide with the use of the external sector of the cave during the late Solutrean as a temporary habitat, as well as a place of parietal symbolic expression. Secondly, that a Gravettian horizon cannot be assumed from the presence of negative stencils in isolation.

We also report a representation of a red deer stag which we consider to belong to the same cultural context as the hand stencil. Put together with previously reported art within the cave (Simón-Vallejo et al. 2008), we may see the hand stencil possibly belonging to a wider artistic framework additionally incorporating naturalistic painting and engravings.

Our result indicates a wide temporal gap between hand stencils in northern Iberia/southern France and southern Iberia. This apparent spatio-temporal gap would need further verification from other southern Iberian sites to establish if it is a widespread phenomenon or a difference specific to the local context of Gibraltar or the south westernmost tip of Europe. In any case, our result highlights the need for further research in this field, supported by direct dating of hand stencils where possible.

It is true that most of the negative hands in a European context and with some kind of chronological approach point to their affiliation to Gravettian moments and, in this sense, the south of Iberia is a territory in which the Gravettian presents a good representation (Cortés et al. 2013, Bicho et al. 2017). However, it is also true that most of the deposits with negative hands do not have direct dating or it is from the analysis of the contexts. So, perhaps we enter into a circular argument by uncritically assigning all hands in negative to presolutrean moments. In this sense, the date obtained in Gorham can serve as a point of reflection on this subject and its chronological ascription.

\section{Acknowledgments}

We would like to thank Dr Javier Fortea and Dr Georges Sauvet for their advice on representations of hand stencils in European Palaeolithic art and a preliminary version of this work.

This study is sponsored by Proyects HAR201344269-P and HAR2016-77789-P from the Spanish Ministerio de Economía y Competitividad. This paper is a contribution of Project HUM-949 (Tellus. Prehistory and Archaeology in the South of Iberia) and the Interdisciplinary Center for Archaeology and the Evolution of Human Behaviour (University of Algarve, Portugal).

\section{REFERENCES}

Aubert, A.; Brumm, A. and Huntley, J. (2018): "Early dates for 'Neanderthal cave art' may be wrong". Journal of Human Evolution 1-3. in press. https:// doi.org/10.1016/j.jhevol.2018.08.004

Baffier, D. and Girard, M. (1992): "La Grande Grotte d'Arcy-sur-Cure (Yonne), nouveau sanctuaire paléolithique. Résultats préliminaires". Revue Archeologique de l'Est et du Centre-Est 43(2): 195-205.

Balbín Berhmann, R. de; Bueno Ramírez, P.; Alcolea González, J.J.; Barroso Bermejo, R.; Aldecoa Quintana, A.; Giles Pacheco, F.; Finlayson, J.C. and Santiago Pérez, A. (2000): The engravings and Palaeolithic paintings from Gorham's Cave, in: Finlayson, C.; Finlayson, G. and Fa, D (eds.), Gibraltar during the Quaternary. The southernmost part of Europe in the last two million years, pp. 179-196. Gibraltar, Government Heritage Publications Monographs 1.

Bicho, N.; Cascalheira, J. and Gonçalves, C. (2017): "Early Upper Paleolithic colonization across Europe: Time and mode of the Gravettian diffusion". PLoS ONE 12(5): e0178506. https://doi.org/ 10.1371/journal.pone.0178506

Cantalejo, P.; Maura, R.; Espejo, M. M.; Ramos, J.; Medianero, J.; Aranda, A. y Durán, J. J. (2006): La Cueva de Ardales: Arte prehistórico y ocupación en el Paleolítico Superior. Estudios, 1985-2005. Málaga, CEDMA.

Clottes, J. (ed) (2003): Return to Chauvet cave: excavating the birthplace of art. London, Thames \& Hudson.

Clottes, J. and Courtin, J. (1994): La grotte Cosquer. Peintures et gravures de la cavernes engloutie. París, Seuil.

Clottes, J.; Courtin, J. and Valladas, H. (1996): "La grotte Cosquer revisité". INORA 15: 1-4.

Cortés-Sánchez, M.; Marreiros, J.M.; Simón-Vallejo, M.D.; Gibaja-Bao, J.F. and Bicho, N. (2013): Reevaluación del Gravetiense en el sur de Iberia, in C. de las Heras, Lasheras, J.A., Arrizabalaga, A. and Rasilla, M. de la (eds.), Pensando el Gravetiense: nuevos datos para la región cantábrica en su contexto peninsular y pirenaico. Monografías del $\mathrm{Mu}-$ seo de Altamira 23, pp. 73-85. Madrid, Museo Nacional y Centro de Investigación de Altamira. 
Finlayson, C.; Finlayson, G. and Fa, D (eds.) (2000): Gibraltar during the Quaternary. The southernmost part of Europe in the last two million years. Gibraltar, Gibraltar Government Heritage Publications Monographs 1.

Finlayson, C.; Giles, F.; Rodríguez-Vidal, J.; Fa, D.; Gutiérrez-López, J.M.; Santiago-Pérez, A; Finlayson, G.; Allué, E.; Baena, J.; Cáceres, I.; Carrión, J.S.; Fernández, Y.; Gleed-Owen, C.P.; Jiménez, F.J.; López, P., López, J.A.; Riquelme, J.A., Sánchez, A.; Giles, F.; Brown, K.; Fuentes, N.; Valarino, C.A.; Villalpando, A.; Stringer, C.; Martínez, F. and Sakamoto, T. (2006): "Late survival of Neanderthals at the southernmost extreme of Europe". Nature 443: 850-853. Doi:10.1038/nature 05195

Fortea, J. (2002): “Trente-neuf dates $C^{14}$-AMS pour l'art pariétal paléolithique des Asturies". Préhistoire, Art et Sociétés, 57: 7-28.

Fortea, J. (2005): La plus ancienne production artistique du Paléolithique ibérique, in: Actas del Simposio Pitture paleolitiche nelle Prealpi venete: Grotta di Fumane e Riparo Dalmieri, pp. 89-99. Verona, Museo Civico di Storia Naturale di Verona MTSN.

Fortea, J. (2007): “39 edades ${ }^{14}$ CAMS para el arte paleolítico rupestre en Asturias", Excavaciones Arqueológicas en Asturias 1999-2002, nº 5, pp. 91-102.

Foucher, P., San Juan-Foucher, C. and Rumeau, Y. (eds) (2007): La Grotte de Gargas. Un siègle de découvertes. Saint-Laurent-de-Neste, Communauté de communes du canton de Saint-Laurent-de-Neste.

Gambier, H.; Beaubal, D.; Airvaux, C.; Aujoulat, J.; Baratin, N. and Buisson-Catil, J. (2007): "New hominid remains associated with Gravettian parietal art (Les Garennes, Vilhonneur, France)". Journal of Human Evolution 53: 747-750. doi:10.1016/j. jhevol.2007.07.003

García-Díez, M. and Garrido, D. (2013): “La cronología de las manos en el arte Paleolítico", in en C. de las Heras Martín, J.A. Lasheras Corruchaga, Á. Arrizabalaga Valbuena, M. de la Rasilla Vives (eds.), Pensando el Gravetiense: nuevos datos para la región cantábrica en su contexto peninsular y pirenaico. Monografías del Museo Nacional y Centro de Investigación de Altamira, $n^{\circ}$ 23, pp. 517-525. Madrid. Ministerio de Cultura.

García-Diez, M.; Garrido, D.; Hoffmann, D.L.; Pettitt, P.B.; Pike, A.W.G. and Zilhão, J. (2015): “The chronology of hand stencils in European Palaeolithic rock art: implications of new U-series results from El Castillo Cave (Cantabria, Spain)". Journal of
Anthropological Sciences 93: 1-18. DOI: 10.4436/ JASS.93004

González, C. (2003): El conjunto parietal paleolítico de la Galería inferior de La Garma (Cantabria). Avance de su organización interna, in: Balbín, R. and Bueno, P. (eds), El arte prehistórico desde los inicios del siglo XXI. Primer Symposium Internacional de Arte prehistórico de Ribadesella, pp. 201222. Ribadesella, Asociación Cultural Amigos de Ribadesella.

Groenen, M. (2012): Recorridos por la Cueva de El Castillo. En busca de la mirada del Paleolítico, in: VV.AA., Arte sin artistas. Una mirada al Paleolítico (Catálogo de exposición), pp. 372-393. Alcalá de Henares, Museo Arqueológico de la Comunidad de Madrid.

Hoffmann, D.L.; Utrilla, P.; Bea, M.; Pike, A.W.G.; García-Diez, M.; Zilhão, J. and Domingo, R. (2017): U-series dating of Palaeolithic rock art at Fuente del Trucho (Aragon, Spain). Quaternary International 432 (2017) 50-58. https://doi.org/10.1016/j. quaint.2015.11.111

Hoffmann, D.L.; Standish, C.D.; García-Diez, M.; Pettitt, P. B.; Milton, J. A.; Zilhão, J.; AlcoleaGonzález, J. J.; Cantalejo-Duarte, P.; Collado, H.; de Balbín, R.; Lorblanchet, M.; Ramos-Muñoz, J.; Weniger, G.-Ch. and Pike, A. W. G. (2018a): "U-Th dating of carbonate crusts reveal Neandertal origin of Iberian cave art". Science 359 (6378): 912-915. doi: 10.1126/science.aap7778.

Hoffmann, D.L.; Standish, C.D.; Pike, A.W.G.; GarcíaDiez, M.; Pettitt, P.B.; Angelucci, D.E.; Villaverde, V.; Zapata, J.; Milton, J.A.; Alcolea-González, J.J.; Cantalejo-Duarte, P.; Collado, H.; de Balbín, R. and Lorblanchet, M. (2018b): Dates for Neanderthal art and symbolic behaviour are reliable. $\mathrm{Na}$ ture Ecology \& Evolution 2: 1044-1045. https://doi. org/10.1038/s41559-018-0598-Z

Jurado, V.; Fernández-Cortés. A.; Cuezva, S.; Laiz, L.; Cañaveras, J.C.; Sanchez-Moral, S. and Saiz-Jiménez, C. (2009): The fungal colonisation of rock-art caves: experimental evidence. Naturwissenschaften 96(9): 1027-1034.

Lasheras, J.A. (2003): El Arte Paleolítico de Altamira, in Lasheras JA (coord) Redescubrir Altamira, pp. 65-91. Madrid, Turner.

Lorblanchet, M. (1995): Les grottes ornées de la préhistoire. Nouveaux regards. Paris, Errance.

Lorblanchet, M.; Cachier, H. and Valladas, H (1989): "Datation des chevaux ponctués du Pech Merle". INORA 12: 2-3. 
Moure, A. and González, M. (1992): "Datation ${ }^{14} \mathrm{C}$ d'une zone décorée de la Grotte Fuente del Salín en Espagne". INORA 3: 1-2.

Mussi, M. (2002): Earliest Italy. An overview of the Italian Paleolithic and Mesolithic. New York, Kluver Academic/Plenum Publishers.

Pearce, D.G. and Bonneau, A., 2018. Trouble on the dating scene. Nature Ecology \& Evolution 2: 925 926. https://doi.org/10.1038/s41559-018-0540-4

Pettit, P.; Arias, P.; García-Díez, M.; Hoffmann, D., Castillejo, A.M.; Ontañón-Peredo, R; Pike, A. and Zilhão, J. (2015): Are hand stencils in European cave art older than we think? An evaluation of the existing data and their potential implications, in Behrmann, R., Bueno-Ramirez, P. and Bahn, P. (eds.) Prehistoric art as prehistoric culture. Studies in Honour of Rodrigo de Balbin, pp. 145-155. Archaeopress. Oxford, British Archaeological Reports.

Pettitt, P. and Pike, A. W. G. (2007): "Dating European cave art: progress, prospects, problems". Journal of Archaeological Method and Theory 14: 27-47. https://doi.org/10.1007/s10816-007-9026-4

Pigeaud, N.; Rodet, R.; Devèse, T.; Dufayet, C.; Trelohan-Chauvet, E.; Betton, J.P. and Bonic, P. (2006): "Palaeolithic cave art in West France: an exceptional discovery: the Margot Cave (Mayenne)". Antiquity 80 (309). http://www.antiquity.ac.uk/projgall/pigeaud/index.html

Pike, A. W. G.; Hoffmann, D.L.; García-Diez, M.; Pettitt, P.B.; Alcolea, J.; De Balbín, R.; GonzálezSainz, C.; de las Heras, C.; Lasheras, J.A.; Montes, R. and Zilhão (2012): "U-Series Dating of Paleolithic Art in 11 Caves in Spain". Science 336: 14091413. DOI: $10.1126 /$ science. 1219957

Pons-Branchu, E.; Bourrillon, R.; Conkey, M.W.; Fontugne, M.; Fritz, C; Gárate, D.; Quiles, A.; Rivero, O.; Sauvet, G.; Tosello, G.; Valladas, H. and White, R. (2014): "Uranium-series dating of carbonate formations overlying Paleolithic art: interest and limitations". Bulletin de la Société préhistorique française 2: 211-224. doi : 10.3406/bspf.2014.14395

Reimer, P.J.; Bard, E.; Bayliss, A.; Beck, J.W.; Blackwell, P.G.; Bronk Ramsey, C; Buck, C.E.; Cheng, H.; Edwards, L.; Friedrich, M.; Grootes, P.M.; Guilderson, T.P.; Haflidason, H.; Hajdas, I.; Hatté, C.; Heaton, T.J.; Hoffmann, D.L.; Hogg,
A.G.; Hughen, K.A.; Kaiser, K.F.; Kromer, B.; Manning, S.W.; Niu, M.; Reimer, R.W.; Richards, D.A.; Scott, E.M.; Southon, J.R.; Staff, R.A.; Turney, C.S.M. and Plicht J. van der (2013): "IntCal13 and MARINE13 radiocarbon age calibration curves 0-50000 years cal BP”. Radiocarbon 55(4): 18691887. https://doi.org/10.2458/azu_js_rc.55.16947

Ripoll, S.; Ripoll, E. and Collado, H. (1999): Maltravieso: el santuario extremeño de las manos. Memoria del Museo de Cáceres 1. Cáceres, Museo de Cáceres.

Sahly, A (1966): Les mains mutilées dans l'art préhistorique. Toulouse, Maison Tunisienne.

Sánchez Moral, S.; Cuezva, S.; García Antón, E.; Fernández Cortés, Á.; Elez, J.; Benavente, D.; Cañaveras, J.C.; Jurado, V.; Rogerio Candelera, M. A. and Sáiz-Jiménez, C. (2014): Microclimatic monitoring in Altamira Cave: Two decades of scientific projects for its conservation. The Conservation of Subterranean Cultural Heritage 18: 139-144.

Simón-Vallejo, M.D.; Cortés-Sánchez, M.; Finlayson, J.C.; Giles, F.; Santiago, A.; Gutiérrez, J. M. and Rodríguez, J. (2005): GI.R.A. project. Prospección y estudio de las manifestaciones artísticas prehistóricas de Gibraltar, in Hernández, M.S. and Soler, J.A. (eds.), Arte Rupestre en la España mediterránea, pp. 277-284. Alicante, Diputación de Alicante.

Simón-Vallejo, M.D.; Cortés-Sánchez, M.; Finlayson, J.C.; Giles, F. and Rodríguez-Vidal, J. (2008): “Arte paleolítico de Gorham's Cave (Gibraltar)". Saguntum 41: 9-22.

Utrilla, P.; Baldellou, V.; Bea, M.; Montes, L. and Domingo, R.(2014): La Fuente del Trucho. Ocupación, estilo y cronología, in: Corchón, $\mathrm{M}^{\mathrm{a}}$.S. and Menéndez, M. (eds.), Cien años de arte rupestre paleolítico. Centenario del descubrimiento de la cueva de la Peña de Candamo (1914-2014), pp. 117-130. Salamanca, Universidad de Salamanca.

Valladas, H.; Cachier, H.; Maurice, P.; Bernaldo de Quirós, F.; Clottes, J.; Cabrera Valdés, V.; Uzquiano, P. and Arnold, M. (1992): "Direct radiocarbon dates for prehistoric paintings at the Altamira, El Castillo and Niaux caves". Nature 357: 68-70. doi: $10.1038 / 357068 \mathrm{a} 0$ 